International Journal of Current Advanced Research

ISSN: O: 2319-6475, ISSN: P: 2319 - 6505, Impact Factor: SJIF: 5.995

Available Online at www.journalijcar.org

Volume 6; Issue 3; March 2017; Page No. 2436-2439

DOI: http://dx.doi.org/10.24327/ijcar.2017. 2439.0023

Research Article

\title{
IMPACT OF BODY MASS INDEX ON LIVER ENZYMES IN POSTMENOPAUSAL WOMEN
}

\author{
Meenakshi Sharma ${ }^{1}$., Sushil Sharma ${ }^{2}$., Shahid Hussain ${ }^{3 *}$ and Zahida Parveen ${ }^{4}$ \\ 1Department of Physiology, Government Medical College, Jammu, Jammu and Kashmir, India \\ ${ }^{2}$ Department of Internal medicine, Government Medical College, Jammu, Jammu and Kashmir, India \\ ${ }^{3}$ Department of Community medicine, Government Medical College, Jammu, Jammu and Kashmir, India \\ ${ }^{4}$ Department of Pharmacology, Government Medical College, Jammu, Jammu and Kashmir, India
}

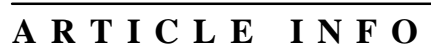

Article History:

Received $10^{\text {th }}$ December, 2016

Received in revised form $7^{\text {th }}$ January, 2017

Accepted $11^{\text {th }}$ February, 2017

Published online $28^{\text {th }}$ March, 2017

Key Words:

BMI, Liver Enzymes, Postmenopausal Women

\begin{abstract}
A B S T R A C T
Objectives: To assess the correlation of BMI with liver enzymes in postmenopausal women.

Methodology: The study was conducted on 100 postmenopausal women in the age group of 45-55 years. Subjects were divided into 3 subgroups: Normal, Overweight and Obese on the basis of BMI. Body weight and height was taken and BMI was calculated using Quetlet index. Early morning Blood samples were taken after a minimum of 8 hours of fasting for assessment of liver enzymes AST and ALT. All parameters were reported as mean and standard deviation. The statistical differences in mean values were tested using Levene' test for equality of variances followed by t-test for equality of means. ANOVA was used to do comparison with in the subgroups. Pearson correlation was used to calculate the correlation between various variables. A p-value $<0.05$ was considered statistically significant and pvalue $>0.05$ was considered non-significant.

Conclusion: A highly significant correlation was seen between liver enzyme AST and BMI in normal, overweight and obese postmenopausal females. There is significant rise of AST levels in obese postmenopausal women.
\end{abstract}

Copyright $\bigcirc 2017$ Meenakshi Sharma et al. This is an open access article distributed under the Creative Commons Attribution License, which permits unrestricted use, distribution, and reproduction in any medium, provided the original work is properly cited.

\section{INTRODUCTION}

Menopause, a normal biological event marked for most women by the end of menstrual periods, signifies the depletion of functional ovarian follicles that are responsible for estradiol production ${ }^{[1]}$. Estrogen deficiency, due to natural menopause or surgical menopause, has been suggested to have an effect on insulin resistance ${ }^{[2,3,4]}$.

Now a days, due to urbanization \& industrialization, there is a dramatic change in lifestyle, consisting of physical inactivity, diet rich in fat, sugar and salt, coupled with a high level of mental stress, weight gain and lifestyle diseases associated with it, which can be prevented due to lifestyle modifications such as diet and exercise ${ }^{[5]}$. So, the current interest is focussed on the abrupt endocrine changes during menopausal transition which have important impact on the physiology of female body, which exacerbate risk for many diseases and disabilities during postmenopausal life ${ }^{[6]}$. This study elucidates the effect of BMI on liver enzymes as a positive relationship of BMI, exists with major coronary risk factors, hypertension and metabolic syndrome ${ }^{[7]}$.

*Corresponding author: Shahid Hussain

3Department of Community medicine, Government Medical College, Jammu, Jammu and Kashmir, India
There is deterioration of metabolic profile with increase in body mass index ${ }^{[8] .}$ Early postmenopausal status is associated with a preferential increase in intra-abdominal fat that is independent of age and total body fat mass ${ }^{[9]}$.

Menopause results in an increase in fat mass and redistribution of body fat, with a relative increase in the proportion of android fat ${ }^{[10]}$. These results may be influenced by a modified energy balance (lower energy expenditure because of less physical activity) but also a decrease in the basal metabolic rate in postmenopausal women ${ }^{[11]}$.

In the present study, liver enzymes AST and ALT were measured in postmenopausal women. These were measured to elucidate the correlation of BMI with liver enzyme. Obesity is one of the risk factors most frequently associated with increased liver enzymes ${ }^{[12]}$.

\section{MATERIAL AND METHODS}

\section{Selection Procedure of the Subjects}

Subjects were selected from different outpatient departments of Government Medical College, Jammu. Subjects included healthy postmenopausal women in the age group of 45 to 55 years. All those women with $\mathrm{H} / \mathrm{O}$ diabetes mellitus, hypertension, neurological disorders, any other illness known 
to affect fasting blood glucose, were excluded from the study, as were smokers and alcoholics. For body mass index, weight was measured in kilograms; on a weighing scale .Height in meter was also measured. Body mass index was calculated using Quetelet's Index ${ }^{[13]}$.

According to the currently recommended cut-offs of BMI recommended by World Health Organization subjects with a BMI of $18.5-24.9 \mathrm{~kg} / \mathrm{m}^{2}$ were classified as normal, while those with a BMI of $25.0-29.9 \mathrm{~kg} / \mathrm{m}^{2}$ were classified as overweight and those with a BMI of $\geq 30 \mathrm{~kg} / \mathrm{m}^{2}$ were classified as obese. So, subjects were divided into subgroups namely normal, over weight and obese.

Specimen collection and handling: Venous blood samples were obtained from the cubital vein after 8-12 hours overnight fasting. Separated plasma or serum specimens are stable for 8 hours at room temperature, 2 days at $2-8^{0}$ Celsius $^{[14]}$.

\section{Estimation of liver enzymes}

1. AST (Aspartate aminotransferase): The AST method based on the dimension clinical chemistry system is an in vitro diagnostic test intended for the quantitative determination of AST activity in human serum or plasma.

The aspartate aminotransferase method is an adaptation of the methodology recommended by the International Federation of Clinical chemistry ${ }^{[15]}$. The method uses the coenzyme pyridoxal 5-phosphate to activate the apoenzyme and lactic acid dehydrogenase (LDH) to eliminate pyruvate interference.

2. ALT (Alanine aminotransferase): The ALT method is based on the dimension clinical chemistry system is an in vitro diagnostic test intended for the quantitative determination of ALT in human serum or plasma.

The alanine aminotransferase method is an adaptation of the recommended procedure of the International Federation of Clinical Chemistry ${ }^{[16]}$. The procedure is based on the principles outlined by ${ }^{[17]}$ but is modified to contain pyridoxal -5-phosphate (PSP) as an activator and to replace phosphate buffer with tris (hydroxymethyl) aminomethane.

\section{Statistical Analysis}

The statistical differences in mean values were tested using Levene's test for equality of variances followed by t-test for equality of means. ANOVA was used to do comparison with in the subgroups. Pearson correlation was used to calculate correlation between various variables.

\section{RESULTS}

Table 1 Mean AST of subjects

\begin{tabular}{cc}
\hline Subjects & Mean AST \pm SD (Range) (in IU/ml) \\
\hline Postmenopausal women & $40.93 \pm 13.31(18-90)$ \\
\hline
\end{tabular}

Table 2 Correlation of BMI with AST in postmenopausal women

\begin{tabular}{|c|c|c|c|c|}
\hline $\begin{array}{c}\text { BMI } \\
\left(\mathrm{Kg} / \mathrm{m}^{2}\right)\end{array}$ & Classification & $\begin{array}{l}\text { Postmenopausal } \\
\text { Groun II (no) }\end{array}$ & $\begin{array}{l}\text { Mean AST } \pm \\
\text { SD (Range) } \\
\text { (in IU/ml) }\end{array}$ & $\begin{array}{c}\text { Pearson } \\
\text { correlation } \\
\text { with n-value }\end{array}$ \\
\hline $\begin{array}{c}18.5 \\
-24.99\end{array}$ & Normal weight & 37 & $\begin{array}{c}31.08 \pm 5.03 \\
(26-42)\end{array}$ & $\begin{array}{c}0.808 \\
P=0.000\end{array}$ \\
\hline $\begin{array}{c}25 \\
-29.99\end{array}$ & Overweight & 34 & $\begin{array}{c}41.55 \pm 11.41 \\
\quad(18-58)\end{array}$ & $\begin{array}{c}0.934 \\
p=0.000\end{array}$ \\
\hline$\geq 30.00$ & Obese & 29 & $\begin{array}{c}52.75 \pm 12.93 \\
(25-90)\end{array}$ & $\begin{array}{c}0.899 \\
p=0.000\end{array}$ \\
\hline
\end{tabular}

Table 3 Mean ALT of subjects

\begin{tabular}{cc}
\hline Subjects & Mean ALT \pm SD $($ Range $)($ in IU/ml) \\
\hline $\begin{array}{c}\text { Postmenopausal } \\
\text { women }\end{array}$ & $57.54 \pm 19.97(25-110)$ \\
\hline
\end{tabular}

Table 4 Correlation of BMI with ALT in Postmenopausal women

\begin{tabular}{|c|c|c|c|c|}
\hline \multirow{3}{*}{ BMI $\left(\mathrm{Kg} / \mathrm{m}^{2}\right)$} & \multirow{3}{*}{ Classification } & Postmenopausa] & $\begin{array}{l}\text { Mean ALT } \pm \\
\text { SD }\end{array}$ & \multirow{3}{*}{$\begin{array}{c}\text { Pearson } \\
\text { - correlation } \\
\text {-with p-value }\end{array}$} \\
\hline & & Group II (no.) & (Range) & \\
\hline & & & (in IU/ml) & \\
\hline $\begin{array}{c}18.5 \\
-24.99\end{array}$ & Normal weight & 37 & $\begin{array}{c}42.51 \pm 9.89 \\
(30-75)\end{array}$ & $\begin{array}{c}0.723 \\
p=0.000\end{array}$ \\
\hline $\begin{array}{c}25 \\
-29.99\end{array}$ & Overweight & 34 & $\begin{array}{c}57.94 \pm 17.59 \\
(25-85)\end{array}$ & $\begin{array}{c}0.963 \\
p=0.000\end{array}$ \\
\hline$\geq 30.00$ & Obese & 29 & $\begin{array}{c}76.24 \pm 16.08 \\
(32-110)\end{array}$ & $\begin{array}{c}0.876 \\
p=0.000\end{array}$ \\
\hline
\end{tabular}

\section{DICUSSION}

Findings in the study were supported by the fact that liver is profoundly affected by obesity where it may be associated with hepatomegaly, increased liver biochemistry values and alterations in liver histology like macrovesicular steatosis, steatohepatitis, fibrosis and cirrhosis ${ }^{[18]}$.

Also, correlation of BMI with ALT levels in the three subgroups (normal, overweight and obese), in perimenopausal women, is highly significant. This is analogus with the study that the mean ALT in persons with increased BMI is higher in than those with normal BMI ${ }^{[19]}$.

Assessed body weight composition in postmenopausal women and determined correlations with metabolic and hormonal parameters $^{[20]}$. The authors found that body mass index values positively correlated with age, time since menopause, parity and glucose, thereby displaying significant correlations with hormonal and metabolic parameters. This is in disagreement with our study as we did not observe significant difference between perimenopausal and postmenopausal women in terms of blood sugar and AST but ALT levels are significantly higher in obese postmenopausal women as compared to perimenopausal women.

Liver plays a major role in carbohydrate homeostasis. Hepatocellular glycogen accumulation leads to hepatic abnormalities in poorly controlled diabetes patients. In hyperglycaemic states, there is accumulation of glycogen in the hepatocytes due to increased glycogen synthesis, causing findings of mild to moderately elevated aminotransferases ${ }^{[21]}$. Non-alcoholic fatty liver disease is the main cause of chronic liver disease associated with obesity ${ }^{[22]}$. Diabetes, steatosis, and age are all significant indicators of cirrhosis.

Liver accumulation of fat in patients with diabetes mellitus or with the insulin resistance syndrome is mainly related to increased lipolysis of adipose tissue, with increased flux of free fatty acids to the liver that exceeds the liver's capacity to export VLDL ${ }^{[23]}$.

Relationship is present between abdominal obesity and serum alanine transferase (ALT) levels and between body mass index and alkaline phosphatase (ALP) levels. These findings suggest that serum ALP, particularly liver ALP, is derived from adipose and hepatic tissue ${ }^{[24]}$. 
Serum alanine transferase (ALT) is commonly used as a diagnostic marker and predictor of many liver diseases. The mean ALT in persons with increased BMI is higher in than those with normal BMI. Liver enzyme tests are commonly used to screen for liver diseases such as fatty liver and hepatitis $^{[25]}$.

Increased levels primarily of alanine aminotransferase (ALT) and triglycerides, and secondarily of gammaglutamyltransferase (GGT), appear to be the most sensitive biochemical indicators of the presence of hepatic steatosis $^{[26,27]}$. Even a minor elevation of ALT is a good predictor of mortality from liver disease ${ }^{[28]}$.

\section{CONCLUSION}

We conclude that highly significant correlation was seen between liver enzyme AST and BMI in normal, overweight and obese postmenopausal females. There is significant rise of AST levels in obese postmenopausal women.

\section{Bibilography}

1. Johnson SR. Women's health issues. Med Clin North Am 1998; 82: 2.

2. Lindheim SR, Buchanan TA, Duffy DM, Vijod MA, Kojima T and Stanczyk FZ. Comparison of estimates of insulin sensitivity in pre- and postmenopausal women using the insulin tolerance test and the frequently sampled intravenous glucose tolerance test. J Soc Gynecol Investig 1994; 1(2): 150-154.

3. Godsland IF. Oestrogens and insulin secretion. Diabetologia 2005; 48(11): 2213-2220.

4. Pirimoglu ZM, Arslan C, Buyukbayrak EE, Kars B, Karsidag YK and Unal O. Glucose tolerance of premenopausal women after menopause due to surgical removal of ovaries. Climacteric 2011; 14(4): 453-457.

5. Pranita A. Pre-diabetes: warning bell for diabetics. Int J Clin Cases Invest 2011; 2(6): 18-26.

6. Mishra SK. Menopausal transition and postmenopausal health problems: a review on its bio-cultural perspectives. Health 2011; 3(4): 233-237.

7. Gupta R, Rastogi P, Sarna M, Gupta VP, Sharma SK and Kothari K . Body mass index, waist size, waist-hip ratio and cardiovascular risk factors in urban subjects. JAPI 2007; 55: 113-118.

8. Parikh P, Mani U and Iyer U. Abdominal adiposity and metabolic control in patients with type 2 diabetes mellitus. Int J Diab Dev Countries 2002; 22: 28-34.

9. Toth MJ, Tchernof A, Sites CK and Poehlman ET. Effect of menopausal status on body composition and abdominal fat distribution. Int J Obes Relat Metab Disord 2000; 24(2): 226-231.

10. Ley C, Lees B and Stevenson JE. Sex- and menopauseassociated changes in body-fat distribution. Am Clin Nutr 1992; 55: 950-954.

11. Poehlman ET, Toth MJ and Gardner AW. Changes in energy balance and body composition 192 at menopause: a controlled longitudinal study. Ann Intern Medicine 1995; 123: 673-675.

12. Robinson D and Whitehead TP. Effect of body mass and other factors on serum liver enzyme levels in men attending for well population screening. Ann Clin Biochem 1989; 26: 393-400.
13. Pranita A, Phadke AV, Singh R, Melinkeri RR and Joshi AR. Prediabetes status in obese and preobese women in the age group 45-49 years. J Assoc Phys India 2012; 60: 121-127.

14. Clinical and Laboratory Standards Institute/NCCLS. Procedures for the Collection of Diagnostic Blood Specimens by Venipuncturing; Approved Standard $5^{\text {th }}$ Edition, CLSI/NCCLS document H3 - A5 (ISBN 156238-515-1). CLSI, 940 West Valley Road, Suite 1400, Wayne, PA, 19087-1898 USA, 2004.

15. Bergmeyer HU, Schelbe $P$ and Nahlefeld AW. Optimization of methods for aspartate aminotransferase and alanine aminotransferase. Clin Chem 1978a; 24(1): 58-73.

16. Bergmeyer HU, Horder M and Moss PN. Provisional recommendations on IFCC methods for the measurement of catalytic concentrations of enzymes. Part 3. Revised IFCC method of aspartate aminotransferase (L-aspartate: 2-oxaloglutarate aminotransferase, EC 2.6.1.1; 1977). Clin Chem 1978b; 24(4): 720-721.

17. Wroblewski F and La Due JS. Serum glutamic pyruire transaminase in cardiac and hepatic disease. Proc Soc Exp Biol Med 1956; 91: 569.

18. Mokdad AP, Ford I and Bowman BA. Prevalence of obesity, diabetes and obesity-related health risk factors. J Am Med Assoc 2001; 289: 76-79.

19. Bilal M, Tariq A, Khan S, Quratulain M, Tariq A and Shahid MF. Influence of gender, BMI and ethnicity on serum ALT levels of healthy students of a medical school. J Ayub Med Coll Abbottabad 2011; 23(1): 7072.

20. Cuadros JL, Fernandez-Alonso AM, Cuadros AM, Chedraui $\mathrm{P}$ and Perez-Lopez FR. Body mass index and its correlation to metabolic and hormonal parameters in postmenopausal Spanish women. Gynecol Endocrinol 2011; 27(9): 678-684.

21. Chatila R and West AB. Hepatomegaly and abnormal liver tests due to glycogenesis in adults with diabetes. Medicine (Baltimore) 1996; 75(6): 327-333

22. Ni H, Soe HHK and Htet A. Determinants of abnormal liver function tests in diabetes patients in Myanmar. Int J Diab Res 2012; 1(3): 36-41.

23. Naveau S, Giraud V, Borotto E, Aubert A, Capron F and Chaput JC. Excess weight as a risk factor for alcoholic liver disease. Hepatol 1997; 25: 108-111.

24. Ali AT, Paiker JE and Crowther NI. The relationship between anthropometry and serum concentrations of alkaline phosphatase isoenzymes, liver enzymes, albumin and bilirubin. Am J Clin Pathol 2006; 126: 437-442.

25. Nomura F, Ohnishi K, Satomura Y, Ohtsuki T, Fukunaga $\mathrm{K}$ and Honda $\mathrm{M}$. Liver function in moderate obesity: study in 534 moderately obese subjects among 4613 male company employees. Int J Obes 1986; 10: 349-354.

26. Bellentani S, Saccoccio G, Masutti F, Croce LS, Brandi G, Sasso F and Cristanini G. Prevalence of and risk factors for hepatic steatosis in Northern Italy. Ann Intern Med 2000; 132: 112-117.

27. Omagari K, Kadokawa Y, Masuda J, Egawa I, Sawa T, Hazama $\mathrm{H}$ and Ohba K. Fatty liver in non-alcoholic non-overweight Japanese adults: incidence and clinical 
characteristics. J Gastroenterol Hepatol 2002; 17: 1098-1105.

28. Kim HC, Nam CM, Jee SH, Han KH, Oh DK and Suh

I. Normal serum aminotransferase concentration and risk of mortality from liver diseases: prospective cohort study. Br Med J 2004; 328: 983-987.

\section{How to cite this article:}

Meenakshi Sharma et al (2017) 'Impact Of Body Mass Index On Liver Enzymes In Postmenopausal Women', International Journal of Current Advanced Research, 06(03), pp. 2436-2439.

$* * * * * * *$ 